\title{
INVESTIGATION OF SORPTION OF 2,4-DICHLOROPHENOL ON SPECIAL HUNGARIAN OIL SHALE
}

\author{
${ }^{1}$ Renáta Rauch, ${ }^{2}$ Rita Földényi \\ ${ }^{1}$ Research Institute of Bio-nanotechnology and Chemical Engineering, University of Pannonia, Egyetem Str. 10.,8200-Veszprém, \\ Hungary \\ e-mail: rauch@mukki.richem.hu \\ ${ }^{2}$ Soós Ernö Water Technology Research and Development Center, University of Pannonia, \\ Egyetem Str. 10.,8200-Veszprém, Hungary \\ e-mail: foldenyi@almos.uni-pannon.hu
}

\begin{abstract}
The development of efficient methods for the removal of different type of organic contaminates of natural waters is an ever challenging task in the modern environmental technology. The paper reports the physical characterization and adsorption properties of a Hungarian oil shale. Static equilibrium experiments were carried out to study the adsorption of 2,4-dichlorophenol (2,4-DCP) from aqueous solution. The obtained equilibrium data were satisfactorily fitted by a multistep adsorption isotherm within the concentration range of 0 to $100 \mathrm{mg} / \mathrm{l}$. According to our laboratory scale experiments the studied row oil shale (OSR) adsorbent immobilizes the contaminants more efficiently than a number of other adsorbents applied in different remediation technologies. More than $90 \%$ of the added 2,4-dichlorophenol was adsorbed by the studied oil shale. The contaminants are bound strongly by the sorbent therefore they cannot be washed out by the groundwater flow which, in turn, favors to the natural bacterial decomposition process of the polluting compound. This is considered as a significant advantage of the adsorbent because no chemical regeneration of the inexpensive oil shale is required. The reported results indicate that the oil shale can be used efficiently for the treatment of natural waters to remove their organic contaminants.
\end{abstract}

Keywords: oil shale, adsorption, 2,4-dichlorophenol

\section{INTRODUCTION}

Water pollution problems caused by organic contaminants emitted by the chemical industry and agricultural activity are especially severe because they threaten both soil and aquatic live too. Chlorophenols are chlorinated aromatic compounds. They are present in surface and subsurface waters as a result of natural degradation of different pollutants released by the agriculture and by various industrial plants (oil, plastics, pharmaceutical, wood preserving etc.) [1].

Chlorophenols are persistent in the environment [2] and can cause toxicity especially by bioaccumulation in animals and plants whereby threatening human health too [3].

The removal of these compounds from contaminated raw water as well as from industrial wastewater is a difficult task. The applied removal techniques typically include adsorption, photocatalytic decomposition and biodegradation as well as different combined methods [4]. The adsorption is one of the most common and established water purification processes [5]. Researchers tested many different types of adsorbents and ion-exchangers for removal of chlorophenols from contaminated waters [3].

The studied oil shale adsorbent contains considerable amounts of clay minerals as well as organic matter too which is finely dispersed in the macro- and micropores of the inorganic matrix. This rock could 
therefore, be utilized as an inexpensive and efficient adsorbent for the removal of substituted phenolic compounds from contaminated waters [7].

Oil shale sources are located at several places of the Carpathian Basin, and especially large amounts can be found in the Hungarian mines. It is an algae based biomass fossil fine-grained sedimentary rock containing large amounts of organic matter, clay volcanic ash and calcium carbonate. The shale originates from the biomass of yellow green algae - genus Botryococcus braunii - accumulated in the volcanic craters over 4 to 5 million years [3].

The organic matter is composed of bitumen and large amount of kerogen [5]. The kerogen is an amorphous, three-dimensional polymer organic matter. It is insoluble in conventional organic solvents [5]. Much of the hydrocarbon is bound because of the low stage of thermal maturity, while the free hydrocarbon (HC) content ranges from $0.1 \mathrm{mg} \mathrm{HC} / \mathrm{g}$ rock to $12.3 \mathrm{mg} \mathrm{HC} / \mathrm{g}$ rock.

Since the 2,4-DCP is an intermediate in the production of different aryloxy alkanoic acid herbicides like the 2,4-dichlorophenoxy acetic acid (2,4-D) and it is also their important degradation product [2], the aim of our work is to investigate the sorption properties of Hungarian oil shale as an adsorbent for the removal of 2,4-DCP from model water samples, under laboratory conditions. The effect of the various parameters such as the initial concentration of the 2,4-DCP, the $\mathrm{pH}$ of the solution and the organic material content of the oil shale were examined.

\section{MATERIALS AND METHODS}

\subsection{Materials and adsorbents}

Analytical grade sodium chloride, sodium dihydrogen phosphate and disodium hydrogen phosphate were obtained from Reanal Chemical Co. (Hungary). The HPLC grade solvent (acetonitrile) was provided by VWR Ltd. (Hungary). The 2,4-DCP standard reference material (>99\%) was the product of Sigma Aldrich. Hungarian oil shale samples were collected from different locations of the mine and were used in this work as adsorbent. The samples were first air-dried, then milled for 1 hour and sieved (particle size below 360 $\mu \mathrm{m}$ was used). Particle size distribution of OSR was measured using Mastersizer 2000 laser diffraction system (Malvern Instruments Ltd). Total organic carbon content (TOC) of adsorbents were determined by Apollo 9000 (TEKMAR DOHRMAN) TOC Analyzer. Nitrogen gas adsorption isotherms (BET surface) and pore size were obtained with ASAP 2000 apparatus.

The main mineral fraction of adsorbents was analyzed using the PHILIPS PW3710 X-ray diffractometer ( $\mathrm{K}$ filter, $\mathrm{Cu}$ radiation $(50 \mathrm{kV}, 40 \mathrm{~mA})$ ). The crystalline phases were identified using the X'Pert Highscore Plus software. Scanning electron microscopy for oil shale samples was conducted using Thermo Fischer APREO SEM attached with EDX units, with accelerating voltage $20 \mathrm{kV}$.

The $\mathrm{pH}$ of OSR were measured by a Radelkis $\mathrm{pH}$ meter (OP-211) using a combined glass electrode (Radelkis, OP-0808P).

The measured physical and chemical properties of the studied OSR are summarized in Table 1 .

DOI: 10.14232/analecta.2018.1.20-29 
Table 1. Characterization of the oil shale (OSR) sorbent

\begin{tabular}{|l|c|}
\hline Properties & OSR \\
\hline $\mathrm{pH}(1 \mathrm{~mol} / \mathrm{L} \mathrm{KCl})$ & 7.21 \\
\hline $\mathrm{BET}^{*}, \mathrm{~m}^{2} / \mathrm{g}$ & 31.87 \\
\hline Typical pore size, $\mathrm{nm}$ & 3.4 \\
\hline Main fraction, \% & 80.8 \\
\hline Particle size, $\mu \mathrm{m}$ & $50-150$ \\
\hline Organic content, \% & 9.79 \\
\hline Carbonate content, \% & 41.2 \\
\hline \multicolumn{2}{|c|}{ Main mineral phases, \% } \\
\hline \multicolumn{2}{|c|}{} \\
\hline Calcite & 23.0 \\
\hline Quartz & 7.3 \\
\hline Siderite & 1.6 \\
\hline Dolomite & 6.2 \\
\hline Albite & 2.5 \\
\hline Caolinite & 1.8 \\
\hline Montmorillonite & 0.6 \\
\hline Illite & 38.7 \\
\hline Amorphous material & 0.7 \\
\hline Secic & 17.7 \\
\hline
\end{tabular}

*Specific surface obtained by BET nitrogen adsorption method

In order to investigate the effect of organic matter content on the extent of adsorption 7 different samples were used (OS2, OS3, OS8, OS9, OS10, OS11, OS12). Their organic content, ignition loss and the main minerals are summarized in Table 2 . 
Table 2. The main components of different oil shale samples

\begin{tabular}{|l|c|c|c|c|c|c|c|c|}
\hline \multirow{2}{*}{ Properties } & \multicolumn{7}{c|}{ oil shale adsorbent } \\
\cline { 2 - 8 } & OS2 & OS3 & OS8 & OS9 & OS10 & OS11 & OS12 \\
\hline $\begin{array}{l}\text { Total organic carbon content of } \\
\text { adsorbent (TOC, m/m \%) }\end{array}$ & 16,7 & 32,8 & 24,8 & 18,3 & 39,8 & 6,85 & 40,1 \\
\hline \multicolumn{7}{|c|}{ Main minerals } \\
\hline Calcite & $\mathrm{X}$ & $\mathrm{X}$ & $\mathrm{X}$ & $\mathrm{X}$ & $\mathrm{X}$ & $\mathrm{X}$ & $\mathrm{X}$ \\
\hline Quartz & $\mathrm{X}$ & $\mathrm{X}$ & $\mathrm{X}$ & $\mathrm{X}$ & $\mathrm{X}$ & $\mathrm{X}$ & $\mathrm{X}$ \\
\hline Siderite & $\mathrm{X}$ & $\mathrm{X}$ & - & $\mathrm{X}$ & $\mathrm{X}$ & $\mathrm{X}$ & $\mathrm{X}$ \\
\hline Dolomite & $\mathrm{X}$ & $\mathrm{X}$ & $\mathrm{X}$ & $\mathrm{X}$ & $\mathrm{X}$ & $\mathrm{X}$ & $\mathrm{X}$ \\
\hline Albite & $\mathrm{X}$ & $\mathrm{X}$ & $\mathrm{X}$ & $\mathrm{X}$ & $\mathrm{X}$ & $\mathrm{X}$ & $\mathrm{X}$ \\
\hline Caolinite & $\mathrm{X}$ & $\mathrm{X}$ & $\mathrm{X}$ & $\mathrm{X}$ & - & $\mathrm{X}$ & $\mathrm{X}$ \\
\hline Montmorillonite & $\mathrm{X}$ & $\mathrm{X}$ & $\mathrm{X}$ & $\mathrm{X}$ & $\mathrm{X}$ & $\mathrm{X}$ & $\mathrm{X}$ \\
\hline Illite & $\mathrm{X}$ & $\mathrm{X}$ & $\mathrm{X}$ & $\mathrm{X}$ & - & $\mathrm{X}$ & - \\
\hline Aragonite & $\mathrm{X}$ & $\mathrm{X}$ & $\mathrm{X}$ & $\mathrm{X}$ & $\mathrm{X}$ & $\mathrm{X}$ & $\mathrm{X}$ \\
\hline Gypsum & $\mathrm{X}$ & $\mathrm{X}$ & - & $\mathrm{X}$ & - & - & $\mathrm{X}$ \\
\hline
\end{tabular}

\subsection{Adsorption studies}

The adsorption isotherms were obtained in a series of batch experiments. The procedure is summarized in the scheme shown in Fig. 1. Static equilibrium experiments were carried out in a solution containing 0.1 $\mathrm{mol} / \mathrm{l} \mathrm{NaCl}$ and $0.01 \mathrm{~mol} / \mathrm{l}$ phosphate buffer of three relevant environmental $\mathrm{pH}$ values $\left(\mathrm{pH}_{1}=5.2 ; \mathrm{pH}_{2}=7\right.$; $\mathrm{pH}_{3}=8.2$ ). 5-5 g of adsorbent were left to swell in $5 \mathrm{ml}$ distilled water for $24 \mathrm{~h}$ at room temperature, then 65 $\mathrm{ml}$ of 2,4-dichlorophenol (solute) in appropriate buffer solutions $(0,10,20,30,40,50,60,70,80,90,100$ $\mathrm{mg} / \mathrm{l}$ ) was added. The suspension was shaken for 1 hour in an orbital shaker then separated by centrifuge at $6000 \mathrm{rpm}$ for $20 \mathrm{~min}$. The supernatant was filtered then analyzed by HPLC.

The percentage removal of adsorbed 2,4-DCP was calculated using the relationship shown by Equ. (1), [4].

$$
\text { Removal }(\%)=\frac{C_{0}-C_{e}}{C_{0}} \cdot 100
$$

where

$c_{0}$ and $c_{e}(\mathrm{mg} / \mathrm{l})$ are the initial and final (equilibrium) concentration of the 2,4-DCP respectively. 


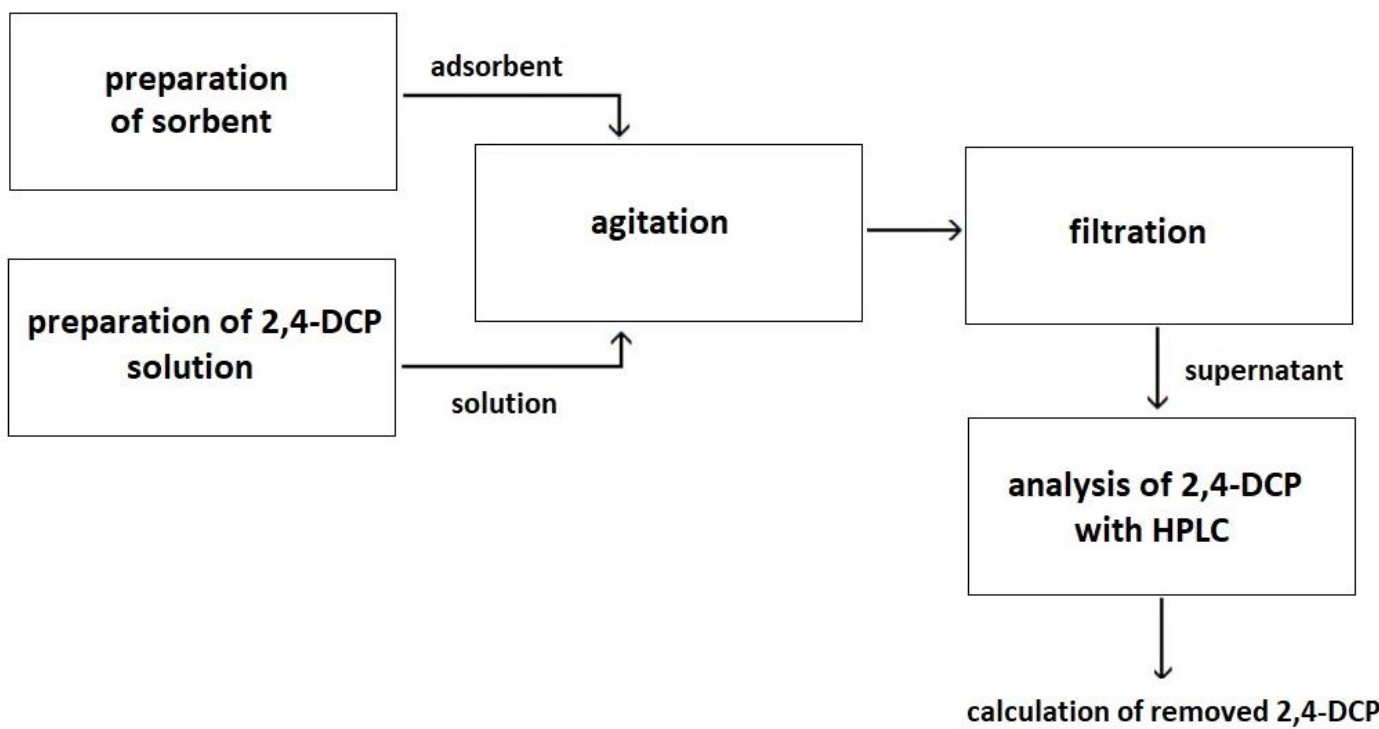

Figure 1. Scheme of the batch experiments

In the supernatant, the concentration of the 2,4-DCP was determined by a MERCK LaChrom HPLC system equipped with a LiChospher 100 column filled with $5 \mu \mathrm{m}$ RP-18 packing material (125 mm x 4 $\mathrm{mm}$ ) and with programmable UV detector. Samples of $10 \mu \mathrm{l}$ injected by an autosampler were isocratically eluted by a hydro-organic eluent containing $65 \%$ acetonitrile and $35 \%$ water; flow rate: $0.7 \mathrm{ml} / \mathrm{min}$; $\lambda=218 \mathrm{~nm}$. The concentration of the standard 2,4-DCP solution used for analytical calibration curve ranged from 1 to $50 \mathrm{mg} / \mathrm{l}\left(\mathrm{R}^{2}>0.99\right)$. The standard deviations of the HPLC determinations ranged from \pm 0.03 to $\pm 1.15 \mathrm{mg} / \mathrm{l}[3]$.

The $\mathrm{pH}$ of the solutions was measured by a Radelkis $\mathrm{pH}$ meter (OP-211) using a combined glass electrode (Radelkis, OP-0808P). 


\section{RESULTS AND DISCUSSION}

The adsorption isotherms are important to describe the solute-adsorbent interaction. A multi-step isotherm model [8] was employed for the numerical fitting of the isotherm data to Equ. (2) by the Microcal TM, Origin 6.0 software.

$$
q=\sum_{i=1}^{s}\left\{\frac{q_{T i} K_{i}\left(c-b_{i}+\left|c-b_{i}\right|\right)^{n_{i}}}{2^{n_{i}}+K_{i}\left(c-b_{i}+\left|c-b_{i}\right|\right)^{n_{i}}}\right\}
$$

where

$c$ is the equilibrium concentration of solution, $[\mu \mathrm{mol} / 1]$,

$s$ is the number of steps of the isotherm $(i=1 \ldots s)$,

$q_{T i}$ is the adsorption capacity, $[\mu \mathrm{mol} / \mathrm{g}]$,

$K_{i}$ is the equilibrium constant, $\left[(1 / \mu \mathrm{mol})^{\mathrm{ni}}\right]$,

$b_{i}$ is the critical concentration limit, [ $\left.\mu \mathrm{mol} / 1\right]$,

$n_{i}$ is the average degree of association assigned to the $i$-th step of the adsorption curve.

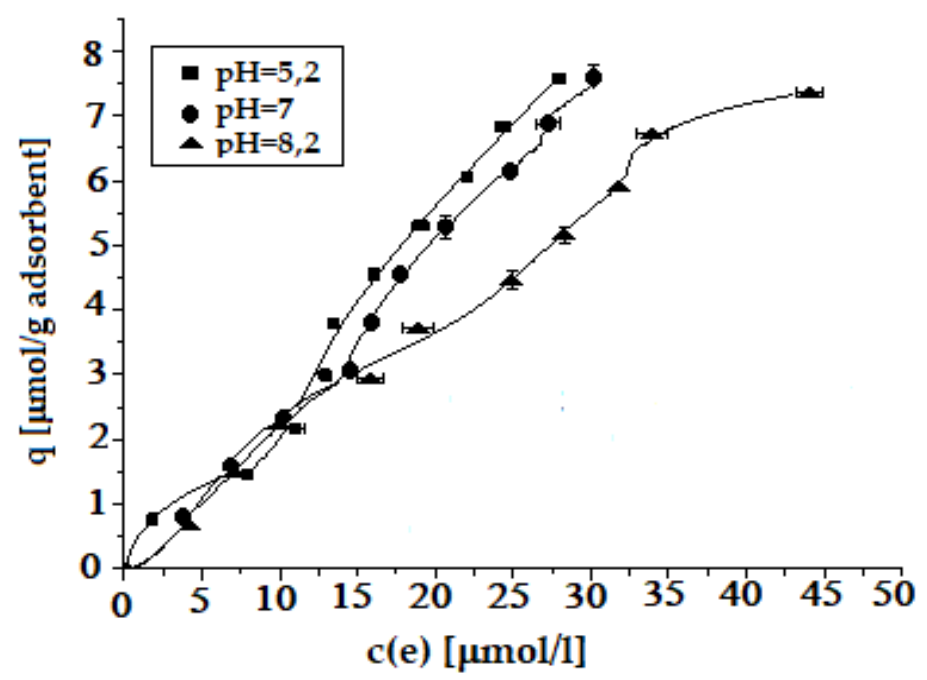

Figure 2. Effect of initial pH on sorption of 2,4-DCP by oil shale (OSR) 
Adsorption isotherms for the 2,4-dichlorophenol on oil shale (OSR) at different initial pH values of the solution are shown in Fig. 2. These curves were fitted by Equ. (2) and the parameters were obtained by a least square procedure. The calculated equilibrium parameters of the adsorption and the related statistical measures of the goodness of fits are presented in Table 3.

Table 3. Calculated parameters of Eq.(2) for the adsorption isotherms of 2,4-DCP at various $\mathrm{pH}$, at $25^{\circ} \mathrm{C}$

\begin{tabular}{|l|c|c|c|}
\hline \multicolumn{1}{|c|}{ Parameters } & $\mathbf{p H}=\mathbf{5 . 2}$ & $\mathbf{p H}=\mathbf{7 . 0}$ & $\mathbf{p H}=\mathbf{8 . 2}$ \\
\hline$q_{T 1}, \mu \mathrm{mol} / \mathrm{g}$ & 54.15 & 11.05 & 7.53 \\
\hline$q_{T 2}, \mu \mathrm{mol} / \mathrm{g}$ & 54.01 & 2.71 & 5.41 \\
\hline$q_{T 3}, \mu \mathrm{mol} / \mathrm{g}$ & 5.09 & 1.62 & - \\
\hline$K_{1},(1 / \mu \mathrm{mol})^{\mathrm{n}}{ }_{1}$ & $5.04 \cdot 10^{-2}$ & $1.48 \cdot 10^{-2}$ & $5.82 \cdot 10^{-3}$ \\
\hline$K_{2},(1 / \mu \mathrm{mol})^{\mathrm{n}}{ }_{2}$ & $3.67 \cdot 10^{-3}$ & 0.21 & 0.12 \\
\hline$K_{3,},(1 / \mu \mathrm{mol})^{\mathrm{n}}{ }_{3}$ & $3 \cdot 10^{-5}$ & 0.32 & - \\
\hline$b_{1}, \mu \mathrm{mol} / 1$ & 0 & 0 & 0 \\
\hline$b_{2}, \mu \mathrm{mol} / 1$ & 48.88 & 56.84 & 70.60 \\
\hline$b_{3,} \mu \mathrm{mol} / 1$ & 70.23 & 100.66 & - \\
\hline$n_{1}$ & 1.19 & 1.07 & 1.38 \\
\hline$n_{2}$ & 0.67 & 0.10 & 0.15 \\
\hline$n_{3}$ & 3.91 & 0.79 & - \\
\hline$\chi^{2}$ & $6.30 \cdot 10^{-2}$ & $8.12 \cdot 10^{-2}$ & $2.06 \cdot 10^{-2}$ \\
\hline$R^{2}$ & 0.99525 & 0.998 & 0.99795 \\
\hline
\end{tabular}

\subsection{The effect of $\mathrm{pH}$}

As can be seen in Fig. 3 and in Table 3, the pH of the aqueous phase is the most important parameter controlling the adsorption efficiency of the chlorophenols [9]. Since the 2,4-DCP is a weak acid $\left(\mathrm{pK}_{\mathrm{a}}=\right.$ $7.85,[10])$, its speciation is governed by the $\mathrm{pH}$. In the $\mathrm{pH}<7.85$ range the dominant form is the neutral, molecular species, while in the $\mathrm{pH}>7.85$, alkaline conditions the negatively charged anionic form dominates in the solution.

The initial parts of the isotherms indicate that in these regions the adsorbed amounts are not markedly influenced by the $\mathrm{pH}$. This is due to the buffer capacity of the adsorbent itself which is efficient enough to maintain a uniform $\mathrm{pH}$ of the solution phase around its own $\mathrm{pH}$ value being $~ 7.2$. At this $\mathrm{pH}$ the 2,4-DCP is mostly occur in neutral form which favors the preferential uptake (sorption) of the contaminant $(7.2<$ $\mathrm{pK}_{\mathrm{a}}=7.85$ ). At higher values of the adsorbed amount, however, the $\mathrm{pH}$ of the solution overwhelms the buffering effect of the adsorbent and the $\mathrm{pH}$ of the solution together with the ionization of the sorbed 2,4DCP become the determinant factor and, as is expected, the adsorbed amounts decrease with the increase of $\mathrm{pH}$. This is quantitatively shown in Table 3 ; the adsorption capacity $\left(q_{1}\right)$ values of the first step of the isotherms are decreasing with the increase of $\mathrm{pH}$. The reason is the electrostatic repulsion between the negatively charged surface of the rock and the phenolic anion. 


\subsection{Effect of organic material content of sorbent}

Comparing the adsorption efficiency of various oil shale samples containing different amount organic phase, it can be seen that the higher is the TOC content the more 2,4-DCP is adsorbed (Fig. 4). It can be supposed that the apolar-apolar interaction works as an efficient sorption mechanism between the organic phase of the oil shale and the phenol species occurring at this $\mathrm{pH}$ dominantly in neutral form.

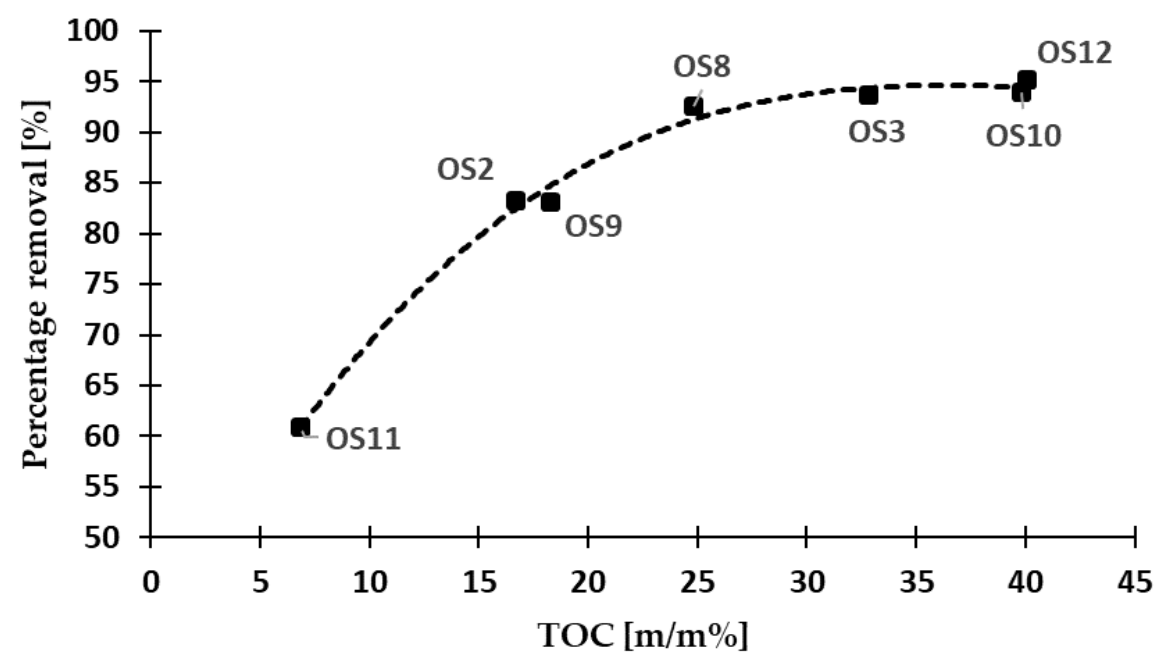

Figure 4. Effect of organic carbon content of oil shale adsorbent

\subsection{SEM micrographs}

The morphologies of the raw oil shale (OSR) and that of the adsorbent after the adsorption of 2,4-DCP were investigated by scanning electron microscope (SEM). The obtained micrographs are shown in Fig. 5. The SEM picture show well preserved fossil colonies of the Botryococcus. The cell content was removed during the fossilization while the outer walls of Botryococcus braunii colonies survived the diagenesis [11]. The SEM shows these empty cells voids surrounded by thick outer walls (Fig. 5 (1)), which were then filled with 2,4-DCP after the adsorption and cover the surface of adsorbent (Fig. 5 (2)). 

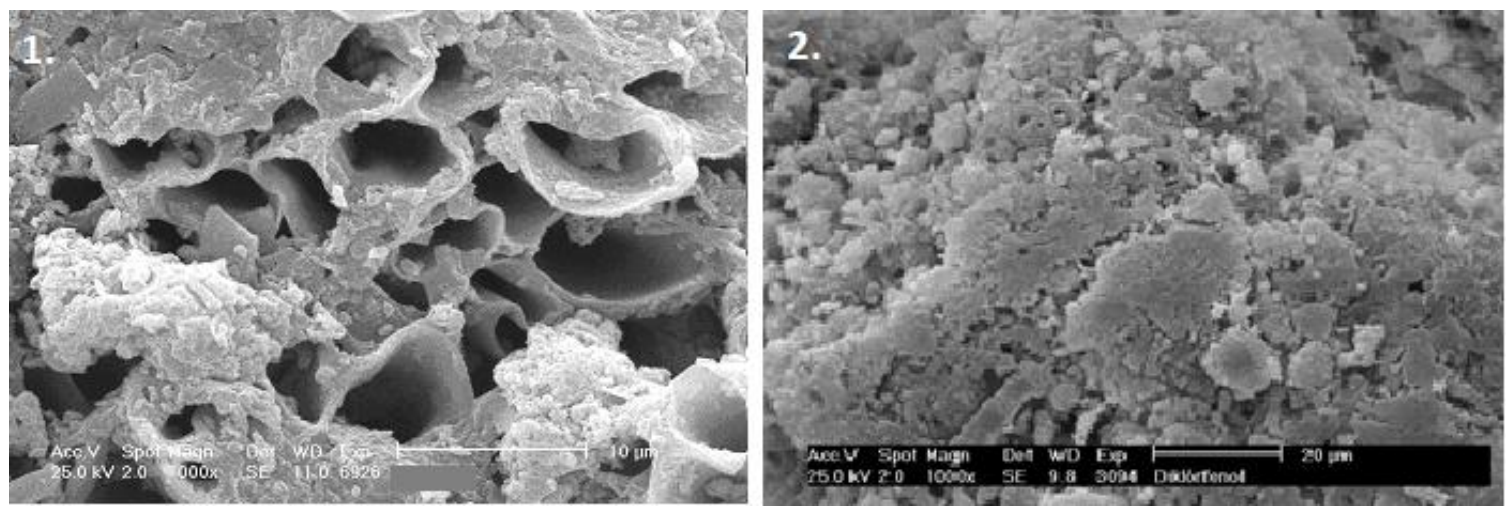

Figure 5. SEM micrograph of raw OSR (1) and with adsorbed 2,4-DCP (2)

\section{CONCLUSION}

Laboratory scale study of adsorption properties of the Hungarian oil shale revealed that it can be used as a low-cost adsorbent for the efficient removal of 2,4-dichlorophenol pollutant from surface and waste waters. Characteristic equilibrium parameters of the adsorption were obtained by fitting a multi-step isotherm equation to the experimental isotherms obtained at the $\mathrm{pH}$ values of 5.2, 7.0 and 8.2. The adsorption is favored by lower values of the $\mathrm{pH}$ and by the higher organic content of the oil shale. SEM micrographs clearly show the open barrel structure of the mineral phase which becomes highly covered after the adsorption of the organic contaminant.

\section{REFERENCES}

[1] Radhika M, Palanivelu K., Adsorptive removal of chlorophenols from aqueous solution by low cost adsorbent - Kinetics and isotherm analysis. J. Hazard Mater. (2006) 138(1):116-24.

[2] M. D. Baker, C. I. Mayfield, Microbial and non-biological decomposition of chlorophenols and phenol in soil. Water, Air, and Soil Pollution, 1980, 13(4):411-424.

[3] Dionýz Vass, Michal Elečko, Vlastimil Konečný, Alginite a raw material for environmental control, Geology Today (1997) 13(4):149 - 153.

[4] Ullhyan A., Ghosh U.K., Removal of 2,4-dichlorophenol by simultaneous adsorption and biodegradation (SAB) using low cost adsorbent. Global Nest Journal (2014) 16(4):616-627.

[5] Sameer Al-Asheh, Fawzi Banat, Asmahan Masad Kinetics and Equilibrium Sorption Studies of 4Nitrophenol on pyrolyzed and activated oil shale residue. Environmental Geology, (2004) 45(8):11091117.

[6] Sameer Al-Asheh, Fawzi Banat, Asmahan Masad, Use of Activated Oil Shale for the Removal of 2,4Dichlorophenol from Aqueous Solutions. Water Quality Research Journal (2005) 40 (2): 211-221. 
[7] J. Hofele, D.Velzen, H. Langenkamp and K. Schaber, Absorption of NO in aqueous solutions of FeII NTA: determination of the equilibrium constant, Chemical Engineering and Processing. (1996) 35:295-300.

[8] Imre Czinkota, Rita Földényi, Zsófia Lengyel, Aurél Marton, Adsorption of propisochlor on soils and soil components equation for multi-step isotherms, Chemosphere, (2002) 48(7):725-731.

[9] Aksu, Z.; Yener, J., A comparative adsorption/biosorption study of mono-chlorinated phenols onto various sorbents. Waste Management (2001) 21:695-702.

[10] C. Namasivayam \& D. Kavitha Adsorptive Removal of 2,4 Dichlorophenol from Aqueous Solution by Low Cost Carbon from an Agricultural Solid Waste: Coconut Coir Pith, Separation Science and Technology, (2005) 39:(6):1407-1425

[11] Sylvie Derenne, Claude Largeau, Magdolna Hetenyi, Alice Brukner-Wein, Jacques Connan, Bernard Lugardon, Chemical structure of the organic matter in a Pliocene maar-type shale: Implicated Botryococcus race strains and formation pathways. Geochimica et Cosmochimica Acta (1997) 61(9):1879-1889. 